\title{
The Population Age Structure, the Real Effective Exchange Rate and the Current Account Balance-Empirical Analysis Based on the Data of Chinese Provincial Panel
}

\author{
Dandan Zhou \\ School of Economics, Jinan University, Guangzhou, China \\ Email: 15521079968@163.com
}

How to cite this paper: Zhou, D.D. (2018) The Population Age Structure, the Real Effective Exchange Rate and the Current Account Balance-Empirical Analysis Based on the Data of Chinese Provincial Panel. American Journal of Industrial and Business Management, 8, 69-82.

https://doi.org/10.4236/ajibm.2018.81005

Received: December 18, 2017

Accepted: January 15, 2018

Published: January 18, 2018

Copyright $\odot 2018$ by authors and Scientific Research Publishing Inc. This work is licensed under the Creative Commons Attribution International License (CC BY 4.0).

http://creativecommons.org/licenses/by/4.0/

\begin{abstract}
This paper takes the panel data of 29 provinces, municipalities and autonomous regions in China as samples from 1994 to 2015, using dynamic panel GMM to analyze the relationship between China's population age structure, the real effective exchange rate and current account balance. System generalized method of moments and robustness test show that the adjustment of China's current projects has obvious inertial characteristics; the change of population age structure has significant negative influence on the current account balance, the impact of youth dependency ratio on the current account is not significant, the elderly dependency ratio has a significant negative impact on current account; the effect of the real effective exchange rate on current account is not significant, the "Theory of Exchange Rate Manipulation in the Chinese Government" is not valid and untenable. The conclusion of this paper shows that the change of population age structure is an important reason for the long-term surplus of China's current account.
\end{abstract}

\section{Keywords}

Youth Dependency Ratio, Elderly Dependency Ratio, the Real Effective Exchange Rate, Current Account, Dynamic Panel Generalized Method of Moments

\section{Introduction}

The balance of payments is one of the four major goals of the country's macroeconomic regulation and control. The current account is the most important item 
in a country's balance of payments. Since 1994, China's current account has a persistent surplus and rapid growth. Especially since 2000, the trade surplus expanded rapidly, from $\$ 174.05$ billion in 2001 to a record $\$ 4205.69$ billion in 2008. Despite the impact of the global financial crisis, the current account surplus has dropped somewhat. However, by the end of 2015, the current account balance of China was $\$ 330.602$ billion, and the large current account surplus still existed (as shown in Figure 1). In addition, a large number of current account surpluses have also brought huge foreign exchange reserves, which has aroused the great concern of our government and the world.

For the reason of China's long-term current account surplus, the main international public opinion is that the Chinese government manipulation of the $\mathrm{RMB}$ exchange rate, causing the value of RMB is seriously undervalued, so as to enhance the product in the international competitiveness of our country. After the "Exchange Reform" in 2005, the RMB began a slow appreciation process. By the end of 2014, the exchange rate of RMB against dollar was 6.14, an increase of $24.29 \%$ since the "exchange reform." Until 2015, "811 New Exchange Reform", the People's Bank of China announced that it would further improve the central parity of $\mathrm{RMB}$ exchange rate formation mechanism, the exchange rate of $\mathrm{RMB}$ against dollar fell $1.8 \%$ on the day, the spot exchange rate of RMB against dollar also fell subsequently. As of December 31, 2015, the exchange rate of RMB against dollar was 6.22284, with 5.77\% depreciation for 2015 (as shown in Figure 1).

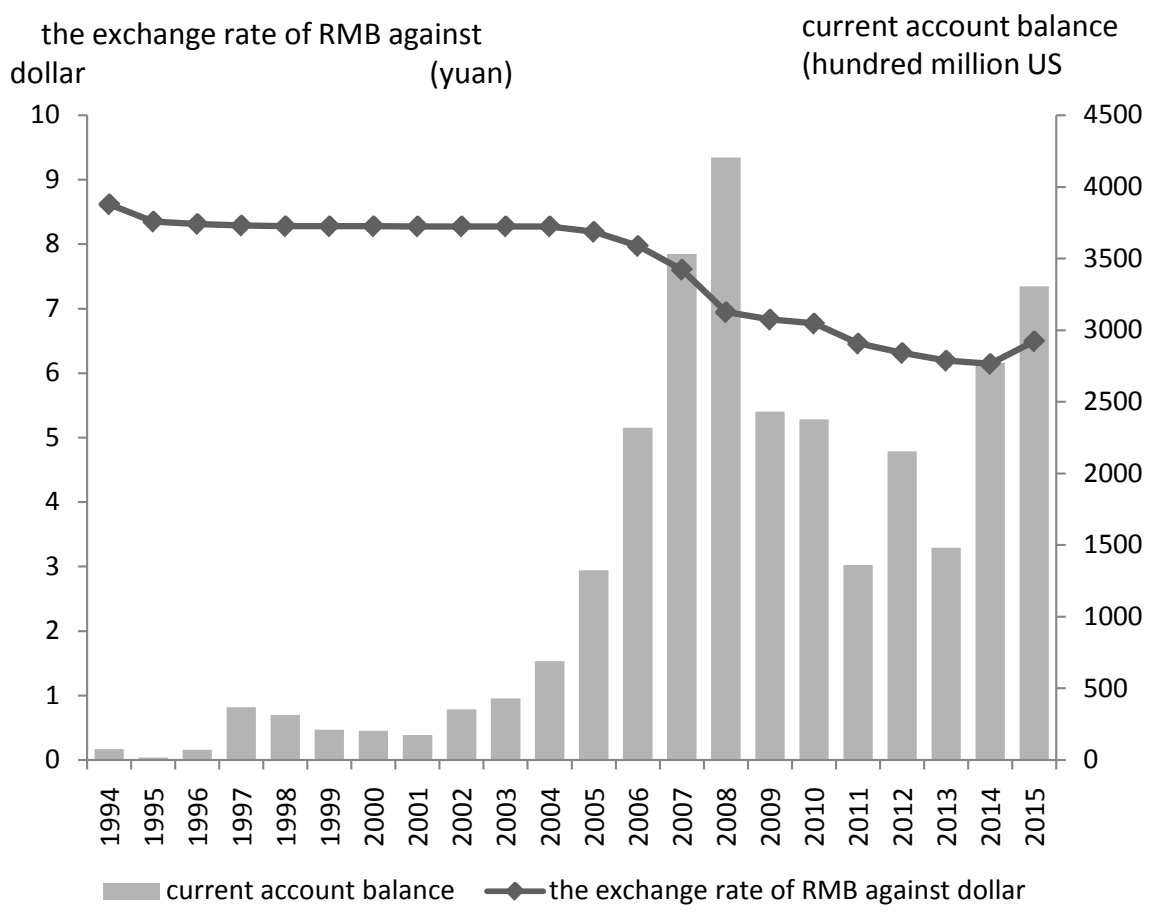

Figure 1. The current account balance and the exchange rate of RMB against dollar from 1994 to 2015. The data source: National Bureau of Statistics, State Administration of Foreign Exchange. 
Since the "Exchange Reform" in 2005, the RMB began a slow appreciation process. The pattern of China's current account surplus has not been effectively improved. These phenomena indicate that the long-term current account surplus is sustained by some long-term factors. Whether the adjustment of the exchange rate of a country can promote the balance of payments of the country or the extent to which it promotes the balance of payments in the country has not consistent conclusion in the prior studies. From the studies of many scholars at home and abroad, we can find that as a long-term and important factor to the economy, the impact of the change in population age structure on the balance of current account of a country cannot be ignored.

Since the reform and opening up, with the implementation of the family planning policy, the population age structure of our country has changed significantly. In the late 1970s, China's dependency ratio was up to $70 \%$, while the sixth census in 2010 dropped to $34.2 \%$. Judging from the proportion of the population living in all stages of life cycle, the proportion of children aged 0 - 14 years in China declines continuously, the proportion of working-age population aged 15 - 64 is on the rise, the proportion of elderly people aged 65 and above increases year by year. By the end of 2014, the proportion of the elderly population aged 65 and over in our country has reached 10.50\% (as shown in Figure 2). According to the International Population Organization, more than 10 percent of the population aged 60 and above, or more than 7 percent of the population aged 65 and above, are in an ageing society. This shows that China has stepped into an aging population. In addition, the total population of China's labor force has been declining in 2012, demographic dividend gradually weakened and Lewis turning point has appeared. At present, the change in the age structure of China's population has fully exposed the problems of population aging and insufficient labor supply. These problems cannot be ignored in the economic development of our country.

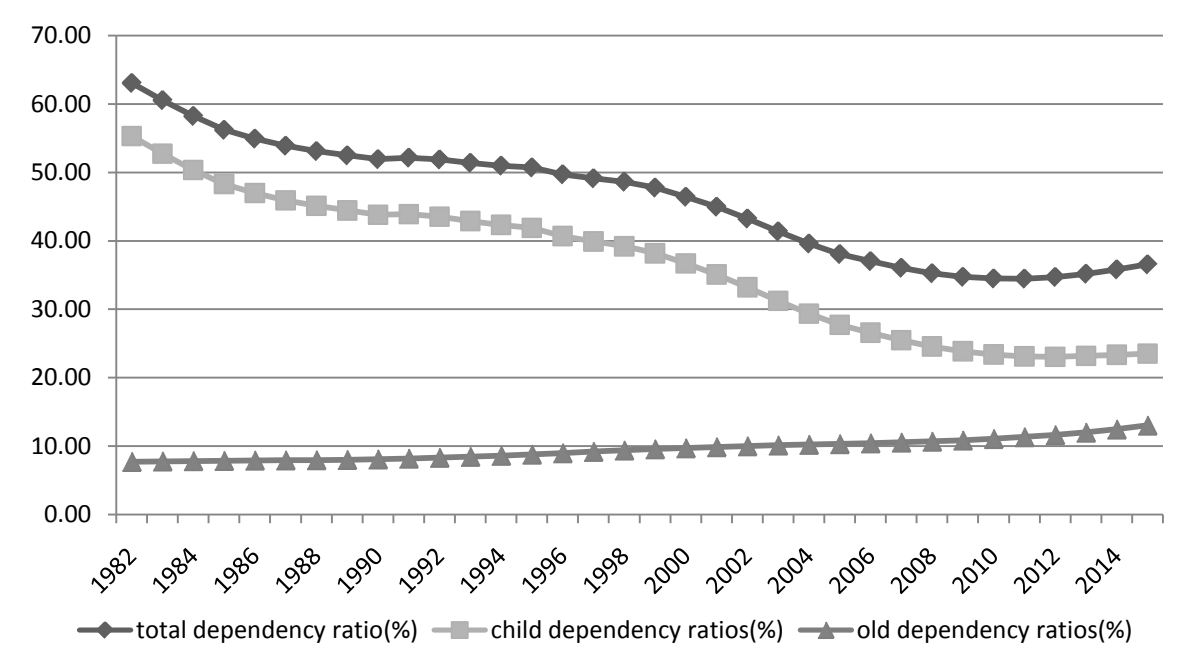

Figure 2. China's dependency coefficient changes from 1994 to 2015. The data source: World Bank website. 
Based on the above problems, this paper analyzes the relationship between the population age structure, the real effective exchange rate of RMB and the current account balance of China through the dynamic panel GMM estimation and China's provincial panel data (1994-2015). According to the test results, we analyze the correlation between RMB appreciation and current account surplus and find out the population age factors that affect current account balance. It not only helps us to accurately grasp the current situation of China's exchange rate, but also predicts the change direction of the current account balance according to the future trend of the population age structure. What is more important is to help us to explore how to effectively regulate our country's balance of payments, thus promoting our country's economic growth under the balance of international payments.

At present, there are relatively few studies on the combination of population age structure, real effective exchange rate and current account balance. Based on the newer and longer provincial inter-provincial panel data from 1994 to 2015 in our country, this paper combine the three with dynamic panel GMM estimation study the relationship between the three, and draw the important impact of the current account balance.

Due to the limitations of obtaining data, this paper is not rigorous enough in the selection of exchange rate data, and the research conclusions are still lack of in-depth discussion. Further in-depth research is needed to provide a more complete explanation of the research question.

\section{Literature Review}

\subsection{Population Age Structure and Current Account Balance}

Foreign studies on the relationship between population structure and current account balance are quite numerous. Coarse and Hoover (1958) put forward the "dependency ratio hypothesis" at the earliest, that is, the higher dependency ratio will reduce the savings rate and thus lead to the current account deficit [1]. This hypothesis laid the foundation for many scholars to study the relationship between population structure and current account.

Fry and Mason (1982) used sample data from more than 50 countries and found that there was a negative correlation between dependency coefficient and saving rate [2]. Taylor and Williamson (1994) analyzed individual savings behavior from the demographic structure, and then concluded that countries with higher dependency ratios have relatively lower savings rates and are prone to larger deficits in the current account [3]. Higgins (1998) using 30-year panel data from more than 100 countries found that there is a negative correlation between population dependency ratio and national saving and current account balances, positive correlation between working-age population ratio and national saving and current account balance [4]. Using empirical panel data from 18 developed countries and 71 developing countries from 1971 to 1995 , Chinn and Prasad (2003) found that population dependency had a negative effect on the 
current account. The impact of youth dependency ratios and old dependency ratios on changes in the balance of payments in a country's mid-term is more significant, but not significant in the short term [5]. Using panel data from more than 20 provinces in China, Li X., Li Z. and Chan M. L. (2012) found that the elderly dependency coefficient has a significant effect on the country's savings, investment and economic growth rates [6].

A great deal of research has been done on the relationship between changes in the population age structure and the current account in foreign countries. Many scholars have concluded that there is a negative correlation between the dependency ratio and the current account balance. In recent years, domestic scholars have also begun to pay attention to the relationship between changes in population structure and the current account.

In China, Wang Renyan (2003) earlier explained the current account balance from the perspective of changes in the age structure of the population. Using the data of our country from 1989 to 2002, it is concluded that the dependency ratio of our country is negatively correlated with the current account balance [7]. Yang Jijun (2010) successively analyzed the negative correlation between population dependency ratio and the balance of savings and current account through the dynamic GMM method and the construction of a four-period iterative model [8]. Wangwei (2012) [9], XieJianguos and Zhang Bingnan (2013) [10] used panel data from 1993-2009 in China and panel data from 66 countries in 1980-2008 respectively. The results show that the youth dependency ratio and the elderly dependency ratio have a negative impact on the country's current account balance. Using empirical panel data from 1994-2011 in 30 provinces in China, Madan and Shi Lingli (2014) found that an increase in the elderly dependency ratio reduces the current account balance, while the youth dependency ratio has no significant effect on the current account balance [11]. Peng Sida and Xiong Mengting (2015) using the VAR model test showed that the age structure differences between China and the United States and their changes are the basic factors leading to the long-term unbalance of Sino-US bilateral trade balance. The relative changes in youth dependency ratio and labor force participation rate in both countries have strong explanatory power, while the explanatory power of elderly dependency ratio is very weak [12].

\subsection{Real Effective Exchange Rate and Current Account Balance}

Elasticity analysis theory is the main theoretical basis for analyzing the relationship between exchange rate and the trade balance of a country. Bickerdike (1920) first mentioned the theory of balance of payments elasticity [13], while Marshall (1929) analyzed the changes of exchange rates and imports and exports by using the principle of demand elasticity [14], which made a great contribution to the final formation of the theory of elasticity of payments. According to the theory of balance of payments elasticity, the fluctuation of exchange rate will affect the elasticity of supply and demand for the import and export of a country's goods so that the country's balance of payments can be adjusted. 
With the theory of elasticity of payments, many Western economists began to study whether M-L conditions can be met in all countries. Because of different research methods, countries, sample sizes and so on, the conclusions drawn by scholars are not consistent. There are mainly two kinds of research points abroad:

First, the impact of changes in exchange rates on trade balances is significant. Krugman and Hooper (1987) [15] and Krugman and Baldwin (1989) [16] analyzed the relationship between real effective exchange rate and trade balance in the United States and concluded that devaluation of the real effective exchange rate is good for improving trade balance. Bahmani Oskooee and Brooks (2006) [17], Bahmani Oskooee and Ratha (2004) [18], Bahmani Oskooee and Ardalani (2006) [19] use bilateral trade data from the United States and its trading partners to point out that the real depreciation of the U.S. dollar has a positive impact on U.S. trade balances. Second, the impact of changes in exchange rates on trade balances is not significant. A study by Ballmani-Oskooee (1985) found that the M-L conditions for developing countries to improve their trade balances by devaluing their currencies were often not established [20]. Research by Hooper and Kohlhagen (1978) [21] and Gotur (1985) [22] and Bailey, Trvlas and Ulan (1987) [23] also showed that exchange rates have no significant effect on trade. Wilsion (2001) [24] found that the real exchange rate changes in Singapore and Malaysia have little effect on their trade with the United States and Japan.

In recent years, some domestic scholars have carried out research on the relationship between RMB exchange rate and trade balance based on China's economic data. The research conclusions can be divided into two categories.

The first type of research holds that there is a significant correlation between RMB exchange rate and trade balance. Lu Xiangqian and Dai Guoqiang (2005) used annual data from 1994 to 2003 and conducted VAR model tests. The results showed that the real exchange rate of RMB had a significant impact on the trade balance of China and the M-L conditions were established in China [25]. Liu Yaocheng, Zhou Jizhong and Xu Xiaoping (2010) found that the RMB exchange rate has a significant impact on the current account. The theory of trade balance flexibility was basically established in China [26]. Liu Hongzhong and Qin Tai (2015) conducted empirical analysis using inter-period analysis of current account. The results show that the intra-period substitution effect brought by the real exchange rate fluctuation is the main reason for the change in the same direction between the current account surplus in China and the appreciation of the RMB since 2005 [27].

The second type of research suggests that there is no significant correlation between the RMB exchange rate and the trade balance. Ye Yonggang, Hu Liqin and Huang Bin (2006) used quarterly data from 1995-2004 to conduct multiple co-integration tests. The test results show that the RMB exchange rate does not have a significant impact on the trade balance [28]. He Liping (2008) breaks down the current account into general trade, processing trade and other trade. After the inspection, it is considered that the real exchange rate of RMB is not 
significant to the current account [29]. Wang Junbin and GuoXinqiang (2011) based on the SVAR empirical analysis of quarterly data from 1992 to 2008, found that there is no negative causal relationship between the RMB exchange rate and the current account balance. The main reasons for the appreciation of the RMB and the current account surplus should be the technical impact of supply [30].

Based on the current research situation both at home and abroad, we find that the research on population age structure and current account, real effective exchange rate and current account have been continuously pushed forward. However, relatively few studies have combined the population age structure, the real effective exchange rate and the current account balance.

\section{Model Setting and Data Selection}

\subsection{The Setting of Empirical Model}

There are many factors that affect current account balances. Although this paper mainly studies the relationship between population age structure, the real effective exchange rate and the current account balance, we must consider the influence of other factors during the measurement analysis or we will miss out important explanatory variables, resulting in unreasonable estimates. This article explains the main sources of variable selection (Peng Sida, Xiong Mengting, 2015; Ma Dan, Shi Lingli, 2014; Wang Wei, 2012, etc.): one is the population age structure and the real effective exchange rate; the other is using the other factors that affect the current account balance except for the above two factors as the controlling variables. Based on the research of many economists, this paper selects the actual per capita national income, the amount of foreign direct investment, the degree of trade openness and the public expenditure as the controlling variables.

Taking into account the inertia of the current account balance, this paper introduced the lag of the current account balance into the regression equation, that is, the dynamic panel data model.

In summary, the test model set in this paper is:

$$
\begin{aligned}
c a b_{i}^{t}= & \alpha+\rho c a b_{i}^{t-1}+\beta_{1} y d r_{i}^{t}+\beta_{2} e^{2} r_{i}^{t}+\beta_{3} \operatorname{lnreeer}_{i}^{t}+\beta_{4} \operatorname{lngdp_{i}^{t}} \\
& +\beta_{5} \text { fdi }_{i}^{t}+\beta_{6} \text { open }_{i}^{t}+\beta_{7} \text { gov }_{i}^{t}+u_{i}+\varepsilon_{i}^{t}
\end{aligned}
$$

In this paper, $i$ is the observed province in the sample, $t$ is the observation time in each province in the sample, $i=1,2, \cdots, 29, t=1994,1995, \cdots, 2015$. $c a b_{i}^{t}, \quad c a b_{i}^{t-1}$ respectively represent the ratio of current account balance to GDP in the period $t$ and $t-1$ of $i$ province, $y d r_{i}^{t}$ represents the youth dependency ratio in the period $t$ of $i$ province, edr $r_{i}^{t}$ represents the elderly dependency ratio in the period $t$ of $i$ province, Inreeer $r_{i}^{t}$ represents the real effective exchange rate in the period $t$ of $i$ province, $\operatorname{lngdp} p_{i}^{t}$ represents the actual per capita national income in the period $t$ of $i$ province, $f d i_{i}^{t}$ represents the amount of foreign direct investment in the period $t$ of $i$ province, open $_{i}^{t}$ represents the degree of 
trade openness in the period $t$ of $i$ province, $g o v_{i}^{t}$ represents the public expenditure in the period $t$ of $i$ province, $u^{i}, \varepsilon_{i}^{t}$ represents the composite error term in the period $t$ of $i$ province.

\subsection{Selection of Variables and Data}

In the selection of data, this paper uses the balance panel data of 29 provinces, municipalities and autonomous regions in China from 1994 to 2015. Due to the lack of data in Chongqing and Tibet, the data of these two provinces were removed. The meaning, calculation basis and descriptive statistics of specific variables are shown in Table 1.

\section{The Empirical Analysis}

\subsection{Dynamic Panel Generalized Method of Moments}

In order to effectively overcome the problems of endogeneity, autocorrelation

Table 1. The meaning, calculation basis and descriptive statistics.

\begin{tabular}{|c|c|c|c|c|c|c|}
\hline & $\begin{array}{l}\text { The meaning and } \\
\text { calculation basis }\end{array}$ & $\begin{array}{l}\text { Number of } \\
\text { observations }\end{array}$ & $\begin{array}{l}\text { Mean } \\
\text { value }\end{array}$ & $\begin{array}{c}\text { The } \\
\text { standard } \\
\text { deviation }\end{array}$ & $\begin{array}{l}\text { The } \\
\text { minimum } \\
\text { value }\end{array}$ & $\begin{array}{c}\text { The } \\
\text { maximum } \\
\text { value }\end{array}$ \\
\hline $\mathrm{cab}$ & $\begin{array}{c}\text { Current account balance } \\
\text { as a share of GDP (\%) }\end{array}$ & 638 & 0.68 & 16.17 & -107.88 & 32.32 \\
\hline$y d r$ & $\begin{array}{l}\text { The youth dependency ratio, } \\
\text { that is, the number of children } \\
\text { aged } 0 \text { - 14/the number of } \\
\text { working people aged } 15-64(\%)\end{array}$ & 638 & 28.86 & 9.65 & 9.64 & 57.56 \\
\hline edr & $\begin{array}{l}\text { The elderly dependency ratio, } \\
\text { that is, the population over the } \\
\text { age of } 65 / \text { the number of } \\
\text { working people aged } 15-64(\%)\end{array}$ & 638 & 11.43 & 2.56 & 5.25 & 21.88 \\
\hline lnreer & $\begin{array}{l}\text { The real effective exchange rate, } \\
\text { that is, the bilateral nominal } \\
\text { exchange rate between China } \\
\text { and the United States * the CPI } \\
\text { of various provinces in China } \\
\text { based on the year of } 1994 / \text { the US } \\
\text { CPI based on the year of } 1994\end{array}$ & 638 & -1.85 & 0.14 & -2.15 & -1.60 \\
\hline $\operatorname{lngdp}$ & $\begin{array}{l}\text { Actual per capita national } \\
\text { income, that is, real GDP per } \\
\text { capita, taking the logarithm }\end{array}$ & 638 & 9.53 & 0.96 & 7.28 & 11.55 \\
\hline fdi & $\begin{array}{l}\text { Foreign direct investment } \\
\text { as a share of GDP (\%) }\end{array}$ & 638 & 3.11 & 3.05 & 0.07 & 24.25 \\
\hline open & $\begin{array}{c}\text { The degree of trade openness, } \\
\text { that is, the ratio of import } \\
\text { and export to GDP (\%) }\end{array}$ & 638 & 31.35 & 39.51 & 3.21 & 217.33 \\
\hline gov & $\begin{array}{l}\text { Public expenditure, that is, } \\
\text { the proportion of local fiscal } \\
\text { expenditure in GDP (\%) }\end{array}$ & 638 & 16.71 & 8.62 & 3.33 & 62.74 \\
\hline
\end{tabular}

Note: The data in this paper comes from China Statistics Bureau, wind database, State Administration of Foreign Exchange and World Bank website. 
and omission of variables, we use the dynamic panel GMM to estimate. The estimation method of dynamic panel GMM mainly has differential GMM estimation and system GMM estimation. Due to the relatively small correlation between the instrumental variables of differential GMM lags and the endogenous variables of differential terms, the problems of weak exogenous instrumental variables are prone to make the estimation biased. Arellano and Bover (1995), Blundell and Bond (1998) proposed another more efficient method, the estimation method of the system GMM. The system GMM is estimated by combining the horizontal regression equation and the differential regression equation. The instrumental variables include not only the lagged difference term but also the lagged horizontal term. Generally, the estimation of system GMM is better. Therefore, this paper chooses the system GMM to estimate. According to the model set in this paper, we have made a regression estimate of 5 models. We start with the addition of three major explanatory variables ydr, edr and lnreer, and then gradually add other explanatory variables to estimate. The specific estimation results are shown in Table 2.

Table 2. The estimation results of SYS-GMM.

\begin{tabular}{|c|c|c|c|c|c|}
\hline Variables & Model 1 & Model 2 & Model 3 & Model 4 & Model 5 \\
\hline cab $(-1)$ & $\begin{array}{c}0.942^{\star * *} \\
(0.056)\end{array}$ & $\begin{array}{c}0.950^{* * *} \\
(0.054)\end{array}$ & $\begin{array}{c}0.932^{\star * *} \\
(0.055)\end{array}$ & $\begin{array}{l}0.933^{* * *} \\
(0.0528)\end{array}$ & $\begin{array}{c}0.935^{\star * *} \\
(0.050)\end{array}$ \\
\hline ydr & $\begin{array}{l}-0.003 \\
(0.029)\end{array}$ & $\begin{array}{l}0.062^{\star} \\
(0.031)\end{array}$ & $\begin{array}{c}0.057^{\star} \\
(0.032)\end{array}$ & $\begin{array}{c}0.059 \\
(0.034)\end{array}$ & $\begin{array}{c}0.018 \\
(0.021)\end{array}$ \\
\hline edr & $\begin{array}{c}-0.078^{\star *} \\
(0.042)\end{array}$ & $\begin{array}{c}-0.115^{\star \star} \\
(0.054)\end{array}$ & $\begin{array}{c}-1.248^{\star *} \\
(0.053)\end{array}$ & $\begin{array}{c}-0.117^{\star *} \\
(0.061)\end{array}$ & $\begin{array}{c}-0.114^{\star * \star} \\
(0.045)\end{array}$ \\
\hline lnreer & $\begin{array}{l}-0.126 \\
(2.217)\end{array}$ & $\begin{array}{l}-4.293 \\
(3.133)\end{array}$ & $\begin{array}{l}-3.603 \\
(3.652)\end{array}$ & $\begin{array}{l}-4.704 \\
(3.549)\end{array}$ & $\begin{array}{c}2.952 \\
(2.107)\end{array}$ \\
\hline $\operatorname{lngdp}$ & & $\begin{array}{c}1.226^{\star * *} \\
(0.409)\end{array}$ & $\begin{array}{l}1.122^{\star *} \\
(0.496)\end{array}$ & $\begin{array}{l}1.324^{\star *} \\
(0.631)\end{array}$ & $\begin{array}{l}1.355^{\star *} \\
(0.658)\end{array}$ \\
\hline fdi & & & $\begin{array}{c}0.038^{*} \\
(0.044)\end{array}$ & $\begin{array}{c}0.055 \\
(0.065)\end{array}$ & $\begin{array}{l}0.095^{*} \\
(0.064)\end{array}$ \\
\hline open & & & & $\begin{array}{l}0.006^{*} \\
(0.009)\end{array}$ & $\begin{array}{c}0.004 \\
(0.009)\end{array}$ \\
\hline gov & & & & & $\begin{array}{c}-0.003^{*} \\
(0.023)\end{array}$ \\
\hline constant & $\begin{array}{c}0.695 \\
(3.305)\end{array}$ & $\begin{array}{c}-20.081 \\
(9.158)\end{array}$ & $\begin{array}{l}-17.666 \\
(11.235)\end{array}$ & $\begin{array}{c}-21.672^{\star} \\
(12.523)\end{array}$ & $\begin{array}{c}-21.607^{\star} \\
(12.496)\end{array}$ \\
\hline Number of observations & 609 & 609 & 609 & 609 & 609 \\
\hline $\operatorname{AR}(1)$ & 0.017 & 0.017 & 0.017 & 0.017 & 0.018 \\
\hline $\mathrm{AR}(2)$ & 0.465 & 0.476 & 0.480 & 0.484 & 0.544 \\
\hline Sargan test & 0.457 & 0.481 & 0.493 & 0.431 & 0.435 \\
\hline
\end{tabular}

Note: In Table 2, the first row of data for each variable represents the regression coefficients and their significance ${ }^{* * *}$ represents significance at $1 \%$ level, ${ }^{* *}$ represents significance at $5 \%$ level, ${ }^{*}$ represents significance at $1 \%$ level); the numbers in parentheses in the second line represent the standard error of the variable. 
The existence of a second-order autocorrelation (AR (2) test) for the differences in the perturbation terms and whether all instrumental variables used are valid or not (sargan test) are the two main test criteria for the system GMM estimation. The AR (1) test and the AR (2) test respectively indicate the first-order correlation test and the second-order correlation test. Their null hypothesis is that there exists sequence autocorrelation. That is, if the test result rejects the null hypothesis, it passes the test, which shows that there is no second-order autocorrelation for the difference of the perturbation term. Sargan test can test the system GMM to estimate whether there is excessive recognition of a tool variable whose null hypothesis is that all the instrumental variables used are valid, that is, if the test result accepts the null hypothesis, the test is passed to indicate that all the tools used All variables are valid.

The results of AR (1) and AR (2) in Table 2 show that the differences of the perturbation terms has a first-order sequence and no second-order sequence is related. We can use the system GMM to estimate. The P value of the sargan test result indicates that the instrumental variables used by the system GMM are valid.

The model 1-model 5 in Table 2 is the system GMM estimation result that continuously joins $y d r$, edr, Inreer, Ingdp, fdi, open and gov. The lagged current account balance and elderly dependency ratio have a significant impact on the current account balance. The impact of youth dependency ratio on the current account balance is mainly insignificant. The impact of the real effective exchange rate on the current account is not significant. The per capita real income, the amount of FDI and the public expenditure all have a significant impact, and the impact of the degree of trade liberalization is not significant. Among the five model estimates, the majority of the $c a b(-1)$ coefficients is around 0.9 and are significant at the $1 \%$ level. This indicates that the early balance of the current account has a great influence on the current balance, and the adjustment of the current account has inertia, which is also the important reason for the long-term surplus of China's current account.

The elderly dependency ratio which is the main explanatory variables in this paper has a significant negative correlation with the current account balance. In Model 5, the explanatory variable edr passed a 1\% significance level. For every $1 \%$ increase in $e d r$, cab will fall by $11.4 \%$. First, according to Modigliani's life cycle hypothesis, the propensity to consume and save is different for people of different ages. If the proportion of the population in a society has changed, the marginal propensity to consume will also change. If the proportion of young people and the elderly in society increases, the propensity to consume will rise and the total savings of society as a whole will decrease, which will have a negative impact on the current account balance. Secondly, a higher dependency ratio for the elderly means that the supply of labor is relatively less, and the relative reduction in the supply of labor has a negative impact on the current account balance. Less labor supply will lead to a decrease in total output and a decrease in domestic supply capacity. However, rising dependency ratio in the elderly will 
lead to an increase in domestic consumer demand. Under this background, exports will be reduced and the current account balance will be somewhat reduced.

The youth dependency ratio which is another explanatory variable of concern to this article has no significant effect on the current account balance, which is not consistent with the conclusions of the life cycle hypothesis. Generally, the influence of youth dependency ratio on the current account balance is consistent with the elderly dependency ratio, that is, the youth dependency ratio has negative influence on the current account balance. However, the regression results in this paper show that the influence of the youth dependency ratio on the current account balance is not significant, most likely because the reduction of the youth dependency ratio does not significantly increase the total social savings. This is mainly because with the improvement of living standards, Chinese parents pay more and more attention to children's material and educational level. Although the birth rate is declining, the number of children per family is decreasing; parents increase the human capital investment of their children and thereby reduce their savings. As a result, the reduction in the youth dependency ratio does not have a significant impact on the current account balance.

There is also a major explanatory variable in this paper that the real effective exchange rate has no significant effect on the current account balance in China. This shows that China's long-term current account surplus is not due to the Chinese government manipulating the RMB exchange rate, which has seriously undervalued the $\mathrm{RMB}$, thereby enhancing the international competitiveness of China's products. The "Theory of Exchange Rate Manipulation in the Chinese Government" is fundamentally untenable and untenable.

The actual per capita income and foreign direct investment have a positive impact on the current account balance and have passed the test at 5\% and $10 \%$ respectively. Public expenditure has a negative impact on the current account balance, with a $10 \%$ level of significance. The effect of the degree of trade openness on the current account balance is not significant.

\subsection{Robustness Test}

In order to test the robustness of the regression model, Mixed Least Squares Estimation (OLS) and Static Fixed Effect Model Estimation (FE) were performed in this paper. Bond (2002) proposed a method to judge whether the GMM estimation has a large degree of bias, that is, whether the estimation result of the coefficient of the first-order lag term in the GMM is between the OLS and FE estimation results. According to the characteristics of OLS estimation, FE estimation and GMM estimation, the first-order lag coefficient of OLS estimation is upward biased while FE estimation is downward biased. Therefore, the first-order lag coefficient of GMM estimation needs to be between the OLS estimation and the FE estimation.

According to Table 3, the dynamic panel model of this paper carries out OLS and FE estimation, the OLS estimated value of cab $(-1)$ is 0.938 , and the FE estimated 0.705 .The SYS-GMM estimate for cab $(-1)$ in Table 2 is 0.935 and 
Table 3. The estimation results of OLS and FE.

\begin{tabular}{|c|c|c|}
\hline Variables & OLS & $\mathrm{FE}$ \\
\hline $\mathrm{cab}(-1)$ & $\begin{array}{c}0.938^{* * *} \\
(0.011)\end{array}$ & $\begin{array}{c}0.705^{\star * *} \\
(0.058)\end{array}$ \\
\hline$y d r$ & $\begin{array}{c}0.113^{* * *} \\
(0.039)\end{array}$ & $\begin{array}{c}0.015 \\
(0.050)\end{array}$ \\
\hline edr & $\begin{array}{c}0.011 \\
(0.082)\end{array}$ & $\begin{array}{l}-0.042 \\
(0.148)\end{array}$ \\
\hline lnreer & $\begin{array}{l}-5.41 \\
(3.252)\end{array}$ & $\begin{array}{l}-7.661 \\
(4.560)\end{array}$ \\
\hline lngdp & $\begin{array}{c}1.801^{* * *} \\
(0655)\end{array}$ & $\begin{array}{l}1.453^{\star} \\
(0.819)\end{array}$ \\
\hline fdi & $\begin{array}{c}0.090 \\
(0.078)\end{array}$ & $\begin{array}{l}0.219^{* *} \\
(0.093)\end{array}$ \\
\hline Open & $\begin{array}{c}-0.017^{* * *} \\
(0.007)\end{array}$ & $\begin{array}{l}-0.030 \\
(0.059)\end{array}$ \\
\hline gov & $\begin{array}{l}-0.019 \\
(0.025)\end{array}$ & $\begin{array}{l}-0.011 \\
(0.025)\end{array}$ \\
\hline Constant & $\begin{array}{c}-29.847^{* *} \\
(12.238)\end{array}$ & $\begin{array}{c}-27.177^{*} \\
(15.124)\end{array}$ \\
\hline Observations & 609 & 609 \\
\hline Adjusted $\mathrm{R}^{2}$ & 0.936 & 0.545 \\
\hline $\mathrm{F}$ & 0.000 & 0.000 \\
\hline
\end{tabular}

indeed lies between the OLS and FE estimates. This shows that the dynamic panel GMM estimation method used in this paper is reasonable.

\section{Conclusions}

On the basis of reviewing and summarizing the influencing factors of the current account balance, this paper makes use of the panel data of 29 provinces, autonomous regions and municipalities from 1994 to 2015 to analyze the relationship between population age structure, real effective exchange rate of RMB and current account balance by dynamic panel GMM empirical test. The test results show that: First, the adjustment of China's current account has obvious inertia characteristics. This shows that in addition to being affected by some unexpected factors, the adjustment of China's current account needs a longer period. Second, changes in the age structure of the population have a long-term negative effect on the current account. The elderly dependency ratio has a significant impact on the current account balance, and the effect of the youth dependency ratio on the current account balance is not significant. Third, the effect of the real effective exchange rate on the current account is not significant at all. It proves that the international public opinion on the "Theory of Exchange Rate Manipulation in the Chinese Government" is untenable. The conclusion of the article shows that the change of the population age structure is an important reason 
that cannot be ignored in the long-term surplus of China's current account.

In the long run, with the acceleration of the population aging, the elderly dependency ratio in China will accelerate and the government will increase the public expenditure on medical care and pension, which will lead to the reduction of the total social savings, thus reducing the current account balance and easing the long-term trade surplus. However, we should also realize that with the demise of our country's demographic dividend, the aging population in China will be at an accelerating stage, which will make the labor force a scarce resource. How to deal with this rapid change in the population age structure will be the issue that the Chinese government must face and solve in the longer term.

\section{References}

[1] Coale, A.J. and Hoover, E.M. (1958) Population Growth and Economic Development in India, 1956-1986. Population, 13, 152. https://doi.org/10.2307/1524483

[2] Fry, M.J. and Mason, A. (1982) The Variable Rate-of-Growth Effect in the LifeCycle Saving Model: Children, Capital Inflows, Interest and Growth in a New Specification of the Life-Cycle Model Applied to Seven Asian Developing Countries. Economic Inquiry, 20, 426-442. https://doi.org/10.1111/j.1465-7295.1982.tb00359.x

[3] Taylor, A.M. and Williamson, J.G. (1994) Capital Flows to the New World as an Intergenerational Transfer. Journal of Political Economy, 102, 348-371. https://doi.org/10.1086/261935

[4] Higgins, M. (1998) Demography, National Savings, and International Capital Flows. International Economic Review, 39, 343-369. https://doi.org/10.2307/2527297

[5] Chinn, M.D. and Prasad, E.S. (2003) Medium-Term Determinants of Current Accounts in Industrial and Developing Countries: An Empirical Exploration. Journal of International Economics, 59, 47-76. https://doi.org/10.1016/S0022-1996(02)00089-2

[6] Li, X., Li, Z. and Chan, M.L. (2012) Demographic Change, Savings, Investment, and Economic Growth: A Case from China. Chinese Economy, 45, 5-20. https://doi.org/10.2753/CES1097-1475450201

[7] Wang, R.Y. (2003) Population Age Structure, Trade Balance and the Adjustment of China's Exchange Rate Policy. World Economy, 9, 3-9.

[8] Yang, J.J. (2010) Demographic Factors Affecting China's Foreign Trade SurplusAn Empirical Analysis Based on the Dynamic GMM Method. Knowledge Science, 9, 90-96.

[9] Wang, W. (2012) Changes in Population Structure and China's Trade Surplus: A Theoretical and Empirical Study. Finance and Economic Research, 8, 26-37.

[10] Xie, J.G. and Zhang, B.N. (2013) Changes in Population Structure and the Adjustment of Current Account Income and Expenditure: A Study Based on Multinational Panel Data. World Economy, 9, 3-24.

[11] Ma, D. and Shi, L.L. (2014) Population Age Structure, Population Industrial Structure and Current Account-An Empirical Study Based on China's Provincial Panel Data. Zhejiang Finance, 4, 17-22.

[12] Peng, S.D. and Xiong, M.T. (2015) Study on the Influence of Population Age Structure on the Imbalance of Trade Balance between China and the United States. International Trade Issues, 6, 72-81.

[13] Bickerdike, C.F. (1920) The Instability of Foreign Exchange. Economic Journal, 30, 
118-122. https://doi.org/10.2307/2223208

[14] Marshall, D. (1929) The Domestic Servants of the Eighteenth Century. Economica, 25, 15-40. https://doi.org/10.2307/2548516

[15] Krugman, P.R. and Hooper, P. (1987) The Persistence of the U.S. Trade Deficit. Economic Activity, 1987, 1-56. https://doi.org/10.2307/2534513

[16] Baldwin, R. and Krugman, P. (1989) Persistent Trade Effects of Large Exchange Rate Shocks. Quarterly Journal of Economics, 104, 635-654. https://doi.org/10.2307/2937860

[17] Bahmani-Oskooee, M. and Brooks, T.J. (2006) The Purchasing Power Parity Puzzle in Developing Countries. In: Morales-Zumaqero, A., Ed., International Macroeconomics: Recent Developments, Nova Science, New York, 53-61.

[18] Bahmani-Oskooee, M. and Ratha, A. (2004) The S-Curve Dynamics of US Bilateral Trade. Review of International Economics, 28, 32-38.

[19] Bahmanioskooee, M. and Ardalani, Z. (2006) Exchange Rate Sensitivity of US Trade Flows: Evidence from Industry Data. Southern Economic Journal, 72, 542-559. https://doi.org/10.2307/20111832

[20] Bahmani-Oskooee, M. (1985) Devaluation and the J-Curve: Some Evidence from LDCs. The Review of Economics and Statistics, 67, 500-504. https://doi.org/10.2307/1925980

[21] Hooper, P. and Kohlhagen, S.W. (1978) The Effect of Exchange Rate Uncertainty on the Prices and Volume of International Trade. Journal of International Economics, 8, 483-511. https://doi.org/10.1016/0022-1996(87)90001-8

[22] Gotur, P. (1985) Effects of Exchange Rate Volatility on Trade: Some Further Evidence. Staff Papers, 32, 475-512.

[23] Bailey, M.J., Tavlas, G.S., Ulan, M., et al. (1987) The Impact of Exchange-Rate Volatility on Export Growth: Some Theoretical Considerations and Empirical Results. Journal of Policy Modeling, 9, 225-243. https://doi.org/10.1016/0161-8938(87)90010-X

[24] Wilson, P. (2000) Exchange Rates and the Trade Balance: Korea Experience 1970 to 1996. Seoul Journal of Economics, 13, 135-164.

[25] Lu, X. and Dai, G. (2005) The Impact of RMB Real Exchange Rate Fluctuation on China's Import and Export: 1994-2003. Economic Research, No. 5, 31-39.

[26] Liu, Y., Zhou, J. and Xu, X. (2010) Dynamic Impact of RMB Exchange Rate Changes on China's Trade Balance. Economic Research, No. 5, 32-40.

[27] Liu, H. and Qin, T. (2015) Relative Price, Income Expectation and Current Account Volatility in China-An Empirical Study Based on the Cross-Term Consumption Perspective of Two Sectors. Financial Research, No. 9, 34-49.

[28] Ye, Y., Hu, L. and Huang, B. (2006) The Relationship between RMB Real Effective Exchange Rate and Foreign Trade Revenue and Expenditure-An Empirical Study of Bilateral Trade Revenue and Expenditure between China and the United States, China and Japan. Financial Research, No. 4, 1-11.

[29] He, L. (2008) RMB Exchange Rate and China's Current Account Surplus in Recent Years. Journal of Financial Research, No. 3, 13-27.

[30] Wang, J. and Guo, X. (2011) Revaluation of the RMB, Current Account Imbalance and China's Technological Progress. Financial Research, No. 11, 47-61. 